\title{
LA ESCRITURA COMO IMAGEN: EL GESTO CALIGRÁFICO COMO RADIOGRAFÍA DE ASPECTOS DE VIDA Y OBRA DE LA ARTISTA COLOMBIANA EMMA REYES.
}

\author{
MARÍA DEL PILAR VERGEL CASTILLA \\ Pontificia Universidad Javeriana Cali \\ ADRIANA MARÍA RÍOS DÍAZ \\ La Sucursal.clo - espacio de arte contemporáneo
}

\section{Resumen}

Con este artículo se busca establecer el vínculo entre escritura, caligrafía y obra de arte de la artista colombiana Emma Reyes (Bogotá, 1919 - Burdeos, 2003), a partir del estudio de fuentes primarias y secundarias (cartas manuscritas, testimonios de entrevistas y referencias textuales en publicaciones sobre arte y periodismo) y su correlación con el método grafológico para la lectura y caracterización de su caligrafía, y así revelar aspectos autobiográficos y biográficos relacionados con su obra.

\section{Palabras Clave}

Escritura, caligrafía, obra de arte.

\section{WRITING AS PICTURE: THE CALLIGRAPHIC GESTURE AS A DEPICTION OF THE ASPECTS OF LIFE AND WORK OF THE COLOMBIAN ARTIST EMMA REYES.}

\section{Abstract}

In this article we are looking to establish a bond between writing, calligraphy and work of art of colombian artist Emma Reyes (Bogotá, 1919 - Burdeos, 2003), based on a study of primary and secondary sources (handwritten letters, interviews testimonies and textual references within art and journalism publications) and their correlation with the graphology method for reading and her calligraphic characterization to reveal autobiographical and biographical aspects related to her work.

$$
\text { Key Words }
$$

Writing, calligraphy, work of art.

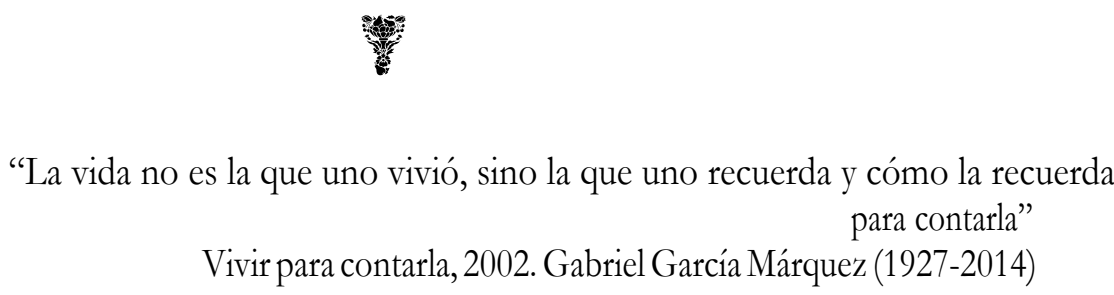

Desde la escritura, Emma es única, como únicos fueron sus dibujos y sus pinturas, el principal insumo de su creación fueron su vida y sus anécdotas, esas que tanto magnetizaron a sus amigos, allegados, a la prensa, a la crítica que no supo comprenderla; precisamente resulta difícil tomar distancia desde la memoria que dictan las imágenes, aquellas que marcan una biografía como la de Emma Reyes. Y esto relacionado con las fuentes documentales que puedan dar testimonio sobre el "carácter" de su 
caligrafía como radiografía sentida de un estado de ánimo revelado en su obra y en las voces de muchos que la acompañaron y valoraron desde diversos ángulos, su peregrinaje. Además de contar con su propia voz, la de Emma Reyes.

Este artículo se plantea en dos partes fundamentales: la primera, establecer el vínculo entre tres conceptos presentes en la vida y obra de la artista colombiana Emma Reyes, escritura - caligrafía - obra de arte, a partir del estudio de fuentes primarias y secundarias, en donde está presente la historia de vida, la anécdota, la voz de la artista, la voz filial y especializada de muchos personas que ayudaron a complementar y a narrar su biografía. La segunda, propone el empleo de un método muy poco cercano al análisis de la obra artística, en forma y contenido, como lo es el método grafológico. Con este medio, se pretende analizar la caligrafía del artista con el fin de revelar algunos aspectos puntuales de su personalidad que están presentes en la construcción misma de su relato-mito y la valoración que el medio artístico le dio a su trabajo plástico.

\section{Algunos aspectos fundamentales para conocer a Emma Reyes}

La frase del historiador y periodista bogotano Germán Arciniegas "Siendo corrosiva e inteligentísima, tiene unos aciertos de gracia que la convierten en una fabuladora incomparable" invita de entrada a conocer a esta mujer, que tal como la describe, correspondería a una semblanza de escritora. Pero es el carácter de una artista plástica nacional la que presenta en su cita. Arciniegas se refiere a su amiga Emma Reyes, artista bogotana que se distinguió en escenarios internacionales, tanto por su obra como por sus relaciones entre los artistas de la época; y especialmente, por el valor que fue tomando su relación con la escritura, siendo este vínculo con Arciniegas y otros autores, uno de los lazos más estrechos que ella establece en su vida porla calidad de los testimonios.

Queda entonces latente la duda sobre su nombre y su connotación en el arte nacional. Emma Reyes es una artista poco estudiada desde la academia y la investigación independiente a nivel nacional. Lo cierto es que su vida y obra definen un contexto cultural y artístico en pleno periodo moderno de la sociedad colombiana, su incidencia en el campo de las artes y la cultura es importante, así la genealogía del arte nacional no la ubique ni siquiera en un lugar reconocible, como muchos otros creadores que tomaron un rumbo similar: emprendieron su periplo formativo y productivo por Latinoamérica y Europa, destinos obligados para cualquier artista de la época, y Emma Reyes no sólo fue la excepción, fue la madrina de los pintores colombianos en París y Roma, la maestra del viaje, de la adaptabilidad, del aprendizaje duro y espontáneo, de las academias extranjeras, de su paso por el cono sur, Francia Estados Unidos, México, Italia, Israel en la famosa ciudad de Haifa, "Ciudad de los artistas" y finalmente en Francia donde ubica su último taller en la ciudad de París, lugar que fue descrito por su misma voz, en artículos de revistas como El Aleph de Manizales, bajo la dirección de Carlos Enrique Ruiz, escritor colombiano y amigo cercano de Emma.

Existen muy pocos referentes bibliográficos sobre Reyes y lo particular es que lo poco que se encuentra es de su mismo puño y letra. Esta particularidad puede constatarse en las pocas fuentes que se encuentran en el país sobre el artista. Sólo en la Biblioteca Luis Ángel Arango de Bogotá, se encuentran 60 registros, 58 son materiales referentes a las obras depositadas en la biblioteca, y sólo 2 artículos, ambos de su autoría. A pesar del árido panorama descrito anteriormente, Reyes fue una escritora aficionada y se han ubicado varios de sus archivos personales en manos de sus amigos más cercanos, asunto que apenas empieza a cobrar fuerza por la importancia documental de su escritura, la cual está íntimamente ligada con su producción plástica.

La problemática de la investigación realizada previamente a este artículo recae en la necesidad de historiar, levantar, revisar, seleccionar el archivo personal, el fondo documental y el acervo productivo de una de las artistas más influyentes del país en el exterior, mentora, "madre" y cómplice de artistas como Fernando Botero, Luis Caballero, Darío Morales, Antonio Barrera y Gregorio Cuartas. Su obra enraizada en los discursos del arte geométrico, trabaja en gran escala pictórica con los géneros más tradicionales del arte (retrato, paisaje, naturalezas muertas) desde un lenguaje contemporáneo para su época. Cabe precisar que estos "cuerpos documentales" se ven reflejados en

\footnotetext{
1 Arciniegas, 1993.
} 


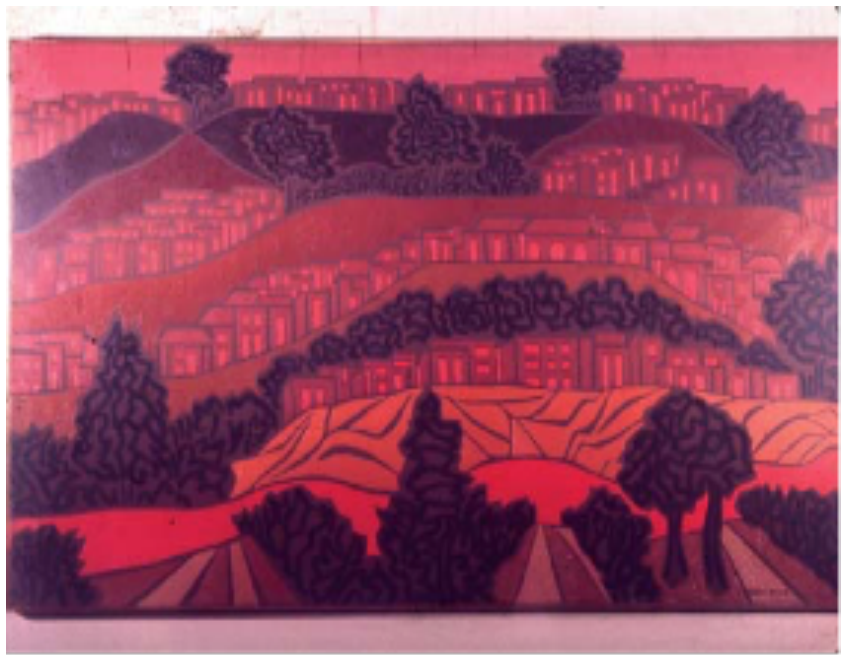

Fig. 1. Haifa. Colección de diapositivas $35 \mathrm{~mm}$. Biblioteca Luis Ángel Arango. Bogotá.

esta primera investigación gracias a la colaboración de los acervos documentales del Museo de Arte Moderno La Tertulia en Cali (su Colección y su Centro de documentación), la Fundación Arte Vivo Otero Herrera con su sede en Málaga España y la Colección de la Biblioteca Luis Ángel Arango del Banco de la República en Bogotá.

Lo cierto es que en la historiografía del arte nacional, los historiadores del arte del período moderno construyeron una historia conocida, destacada por genios masculinos (Alejandro Obregón, Enrique Grau, Eduardo Ramírez Villamizar, Edgar Negret como los grandes modernos) y figuras preponderantes planteados desde discursos masculinos o extranjerizantes de críticos y curadores; además de priorizar gustos particulares, desestimando desde sus inicios artistas que aportaban a la disciplina por divergencias en sus posturas ideológicas, de género o por el simplehecho de producir fuera del país, como es el caso de Reyes.

Resulta importante destacar varios aspectos relevantes a la hora de "leer" la obra de Emma Reyes, el legado de su acervo personal presente en cartas y referencias de otros autores, cercanos o no a ella, unos bajo un discurso especializado, otros más bien coloquial y sentido en la anécdota. Germán Arciniegas, escritor colombiano y amigo personal de Emma, la llamaba Emmísima. Eran confidentes y compartían el amor y oficio por la escritura. En breve, Arciniegas presenta el periplo de vida de Reyes con las siguientes palabras:

"Emma es polémica. Contradictoria. Subversiva. Es ese tipo de suramericano fabuloso que sorprende imaginando. Arma tertulia en México con Diego Rivera, en Roma con Alberto Moravia, en París con los existencialistas de Sartre. Alberto Moravia y Elsa Morante en Roma son sus confidentes. Es la madrina de cuanto pintor colombiano llega a París. ¿Cómo ha llegado a la tertulia de los de Sartre, a encontrarse con Ezra Pound, a las tertulias de los estudiantes a que la llame Giulietta Massini, a que la elogie Diego Rivera, a que la quiera como hermana María Zambrano, a que la necesite Atahualpa Yupanqui, a que todos la quieran. Jamás adulando, polemizando sí, levantando el argumento contradictorio en un francés roto, en un castellano que no es"2

El vínculo de su amistad los llevó a sostener una relación epistolar nutrida y de total complicidad. De igual forma se forjó la relación que Emma estableció con Maritza Uribe de Urdinola, (fundadora del Museo de Arte Moderno La Tertulia de Cali) y con Gloria Delgado, miembros activos de la cultura caleña de la década del sesenta al noventa, quienes acompañaron a Emma en sus iniciativas de exhibición, valorando y divulgando su trabajo en las pocas ocasiones que expuso en el país. Colmada de cariño y admiración, fue una relación basada en el respeto por el trabajo mutuo y por un singular orgullo que Emma les profesaba por los proyectos culturales que emprendían, destacando en gran medida la relación cálida y fraterna que sostenían en el Museo con los artistas, aspecto que Emma

\footnotetext{
2 Arciniegas Germán (1992): “Cosas de Emma Reyes”. Periódico El Tiempo. Bogotá. 20 de febrero. Recuperado el 5 de noviembre de 2014 en: http://www.eltiempo.com/archivo/documento/MAM-40478.
} 
valoraba y elogiaba enormemente. Tanto con Arciniegas como con Uribe de Urdinola, Emma conversaba en todos los términos: desde lo más íntimo de sus vivencias, pasando por la crítica al medio artístico, su modus vivendi en Europa, y aunque hablaba poco de su obra y más de su vida personal, su auto reflexión resulta útil ante la falta de fuentes de crítica y estudio sobre su trabajo y su pensamiento.

“[...] estoy escribiendo un libro, no de crítica, porque considero que el artista cree más en lo suyo y no tiene serenidad objetiva para juzgar a los demás, sino de testimonio, sobre la vida de todas estas personas que he encontrado en mi vida y sobre mis amigos pintores. Considero que es una obligación moral contar estas cosas, porque creo que ha llegado el momento de formarnos una mejor conciencia histórica, y eso a todos los niveles, no sólo en arte. Esas anotaciones se publicarán después de mi muerte, porque, si no, alguien podría darme 40 cuchilladas... Es un poco de todo, no solamente de los artistas, sino de hechos políticos muy importantes que me ha tocado vivir de cerca, sobre todo en países latinoamericanos"3.

Siguiendo con el carácter y valor de la amistad con Arciniegas, resulta interesante recordar en plena voz de Emma, como se conocieron:

"Lo vi por primera vez en París, en 1947. Fui invitada por la Embajada de Colombia a un acto de la firma de los "Derechos del hombre" en la Unesco, [...] En un ascensor íbamos tres personas: Germán Arciniegas, otro señor y yo; nadie conocía a nadie. [...] Se trataba de Lin-Yu Tang, de quien me había leído su libro "La alegría de vivir", [...] Ese señor hablaba solo en el ascensor, y los otros dos soltamos la carcajada. Germán se le presentó, y yo también lo hice diciendo "soy Emma Reyes”. Germán Arciniegas volteó a decirme: "¿Usted es la colombiana Emma Reyes...?, pero no..." Y hasta hoy ha existido una profunda amistad entre los dos, sin una nube de por medio. Poseo tal vez unas cinco mil cartas de él, y en todas me llama Emmísima. Es un hombre transparente y generoso"4.

Y para culminar este aparte en donde se perfila la exuberante personalidad de la artista, en la que claramente impera la narración de vida sobre su obra —o como insumo de ella—, se destaca la voz de la periodista cultural Alba Lucía Ángel, en entrevista con Emma, quien le confiesa otras inclinaciones y gustos más allá del arte, y que permite dilucidar otras facetas de su pensamiento y posturas personales.

"Y a Emma le gusta de la vida el ser humano, sobre todo, y le pide lucidez, al máximo, me explica, poder comprender hasta el fin, no perderse de vista, jamás, la zalamería, la hipocresía es lo que más rechaza. Ser actriz de teatro!, ah sí, el sueño de mi vida, si no fuera pintora, y cambia de voz para decirme, ¿feminismo?, yo estoy en contra de eso: tal vez el día en que los hombres le den de mamar a los niños creo en la tal, igualdad, qué va: la mujer es un producto de la educación; es un proceso individual y considero la pelea de los sexos como una guerra imbécil"'5.

Y sobre su educación, Emma tendría mucho que decir. Criada en un hospicio, aprendió a leer y escribir ya siendo una adolescente. Recibió una férrea educación católica que le permitió imaginarse el mundo, más allá del temor de Dios y la condición misma de género. Sus primeras líneas fueron las del bordado y los dechados de costura. Estas labores fueron su primera caligrafía y acercamiento con su dibujo y su pintura.

\section{Aproximación metodológica a la técnica grafológica.}

A partir del estudio de fuentes primarias y secundarias (cartas manuscritas, testimonios de entrevistas y referencias textuales en publicaciones sobre arte y periodismo) se analizan algunos aspectos psicológicos (aptitudes y actitudes) de la artista colombiana Emma Reyes, que se vinculan a su autobiografía y su obra planteada en series donde prima el dibujo como una manifestación gráfica, capaz de emular la escritura y posterior manifestación de su historia de vida. Se empleó para este análisis el método grafológico para la lectura y caracterización de su caligrafía, como "prueba" capaz de narrar, relacionar y confirmar su perfil psicológico con su producción artística y su historia

\footnotetext{
${ }^{3}$ Calderón, p. 51.

${ }^{4}$ Ruiz, 1999: p. 22.

5 Ángel, 1976.
} 
Fig. 2. Sol en la empalizada (por menor), 1968, Collage, Colección de diapositivas $35 \mathrm{~mm}$. Biblioteca Luis Ángel Arango. Bogotá.

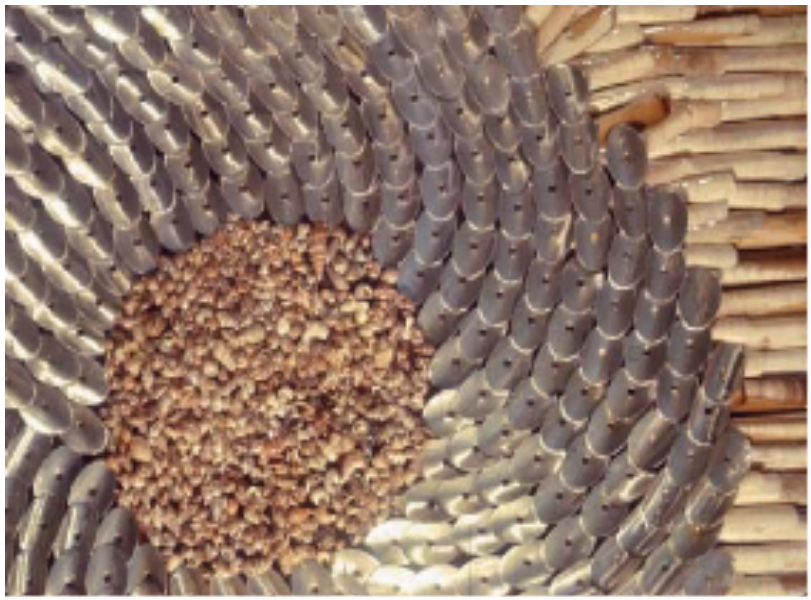

personal, con el firme propósito de establecer posibilidades investigativas, aparentemente "ajenas" a la historia y la teoría del arte y que resultan reveladoras e interesantes a la hora de emplearlas. El aspecto simbólico de la caligrafía se presenta en este análisis como un dibujo adicional cargado de sentimiento. Frases y letras capaces de develar a una mujer fabuladora y vivaz, que evidencia constantemente su historia de vida como el insumo principal de su trabajo artístico.

Para ahondar en el método, se consultó a la abogada y grafóloga colombiana Olga Patricia Trujillo Valencia, con 20 años de experiencia en el campo. Como primer ejercicio, se realizó una entrevista semi-estructurada y exploratoria con Trujillo, con el ánimo de conocer el método y las características físicas que las letras y la construcción de las frases como imagen en una página pudiera revelar (cualquiera que fuese su formato, cartas, postales, tarjetas). La indagación empezó con la revisión (visionado de la construcción de la escritura en la página) y lectura de dos cartas de su puño y letra, sin haber proporcionado ningún tipo de información a la grafóloga sobre la autora, ninguna referencia, dato o seña que pudiera condicionar la lectura, asunto que según el procedimiento siempre resultara irrelevante, lo importante es la imagen del texto. Partiendo de dicha lectura e interpretación de las formas de las letras e inclinaciones de las mismas en el plano del formato de la hoja, se identificó un listado de características o aspectos psicológicos y motivacionales que arrojó su caligrafía en 2 de sus cartas dirigidas a su amiga, Maritza Uribe de Urdinola. (1.carta manuscrita del 13 de Diciembre de 1985 escrita en Bordeaux y 2. carta manuscrita del 1 de Julio de 1983 escrita en París).

A continuación se presentan 23 aspectos relevantes en el ejercicio de lectura de las cartas mencionadas anteriormente. Tomando literalmente, y en orden de aparición, los aspectos referenciados por la grafóloga, se presentan los siguientes:
"1) Autoritarismo, voluntad de poder y de ejercer mando: 2) Capacidad de influenciar a los demás, imponiendo sus ideas y conceptos; 3) Generosa, amplitud mental, visión global; 4) Atenta, concentrada;5) Entusiasta; 6) Creativa; 7) Excelente comunicación. Fluidez verbal; 8) Necesidad de expandirse, trataba de frenar su tren de vida y no le era posible; 9) Ambivalente, entre lo instintivo y lo altruista; 10) Cansancio físico o mental. O tendencia a la tristeza o depresión; 11) Materialista; 12) Consecuencia entre lo que pensaba y hacia;13) Melancólica;
14) Conflicto con su procedencia familiar, no le gustaba que la identificaran con su familia; 15) Capacidad de engañar; 16) Dependencia afectiva; 17) Desordenada; 18) Egoísta; 19) Sobreprotectora; 20) Finura intelectual; 21) Futurista, progresista; 22) Activa; 23) Necesidad de dar y sentir afecto"'.

Algunos de estos aspectos han podido ampliarse y constatarse por medio de una búsqueda y análisis de fuentes que permiten describir el aspecto psicológico per se de Emma Reyes, así como su estado de ánimo en el momento en que fue escrita la carta analizada. Entrelos aspectos gráficos que

\footnotetext{
${ }^{6}$ Diagnóstico realizado durante entrevista, el 31 de mayo de 2014, por Olga Patricia Trujillo Valencia. Nacida en Manizales, Colombia. Abogada, especialista en Derecho empresarial y con conocimientos avanzados en grafología, con experiencia laboral de 20 años.
} 
ayudaron a la grafóloga a definir el perfil psicológico de Emma Reyes "retratada" en sus letras, se destacan las letras abiertas como la $\mathrm{g}$ y la q, que marcan una personalidad fabuladora y ficcional, o las terminaciones de letras como la 1 o la p que cuando se estilizan, denotan finura intelectual; también el gesto de la escritura que se circunscribe en las márgenes de la página, denotan la necesidad de expandirse; así como un párrafo que se aleja del margen con un indentado severo, que cae irremediablemente hacia los lados, manifiestan tristeza y frustración en el momento de la escritura, tal como sucede en otras cartas consultadas como la del 20 Julio de 1990 en donde Emma le cuenta a Maritza Uribe sobre la muerte del artista colombiano Antonio Barrera.

Las citas textuales de periodistas, críticos, historiadores del arte, escritores, colegas artistas y amigos personales que están relacionadas a continuación, fueron empleadas como parte del método que ayuda a identificar algunos de los 23 aspectos revelados, en las cuales se referencia, tanto la voz del artista como otras voces especializadas y no especializadas sobre su vida y obra. En otros casos se conjugan dos aspectos o características que se encuentran referenciados en las mismas fuentes y voces. Aquí parte el análisis.

Sobre Emma se escribieron muy pocos artículos críticos, en los que principalmente se reseñaban aspectos de su personalidad. Estas fuentes centralizan la atención en sus múltiples anécdotas, que son de una increíble fabulación y en las que se despliega sobre sus orígenes un manto de misterio debido a que es emparentada con un ex presidente de Colombia, hecho que no niega ni afirma, y de este modo mantiene — sin saber si es su propósito- un creciente interés sobre este tema. Por otro lado, en sus anécdotas de viajes se hace evidente una mujer de carácter fuerte, capaz de lidiar con situaciones extremas e inverosímiles. Conoció y se relacionó con intelectuales, políticos, literatos, escritores, músicos, artistas plásticos de múltiples nacionalidades, con quienes cultivó y mantuvo una fuerte amistad por el resto de su vida.

Su personalidad impactante se sobrepone a su propuesta plástica, en sus entrevistas sus historias personales son reiterativas y terminan siendo el punto focal de atención, aún en las que pretenden reseñar su obra. En consecuencia queda en deuda el estudio juicioso de su producción artística. Sobre esto, ella asegura que "la enemiga de mi obra soy yo misma. Se suele dar más importancia a las anécdotas de mi vida que a mi arte, esto no debe ser asî"

"'El Mito de Emma', frase que utilizan en repetidos artículos, condensa sus reseñas (que inician con el auto-stop que hiciera para llegar a Argentina) repitiendo en todas ellas sus recorridos de forma tan parecida que casi pueden 'calcarse ; por otro lado, se encuentran las mismas frases que contienen un compendio de sus exposiciones y de lo que otros escribieron de su obra en Europa y Medio Oriente, lo que da cuenta de que su personalidad estuvo efectivamente por encima de su obra. La crítica e historiadora del arte Martha Traba hace alusión a la falta de revisión y estudio del trabajo de Emma Reyes, debido a que su personalidad era preponderante a la hora de entrevistarla, lo cual eclipsaba su discusión"8.

De Emma Reyes conocía solo la anécdota. Hay personas cuya vida se va adentrando en los otros sin que ellos mismos lo sepan. Emma era para mí como un fantasma familiar, un nombre que aparecía en las conversaciones y llegaba a ser tan habitual en ellas como un muro. Era una construcción deshumanizada de cuentos romanos y parisinos: mezcla incierta de narraciones que llegaban de Israel o recuerdos de Argentina, y, además, una sombra quepintabaalparecer—siesque uno puede fiarse de lo que le cuentan-bien?

La obra de Emma está emparentada con la escritura, un grafismo que se desarrolla a lo largo de toda su producción. El pintor colombiano Luis Caballero señalaba que "lo más interesante en la obra de Emma Reyes desde un punto de vista meramente formal es el grafismo, que ha sido una constante en su trabajo" así mismo afirma que "[...] el grafismo es lo primordial en su obra" 10 . En este sentido, define su obra como "Grafías con sentido" $"$.

\footnotetext{
${ }^{7}$ Valencia Diago, 1996: p. 37.

${ }^{8}$ Ríos, 2014: p. 24.

${ }^{9}$ Montaña, 1960: p. 5.

10 Penilla Céspedes, 1991: p. 13.

11 Caballero, 1996, p. 35.
} 


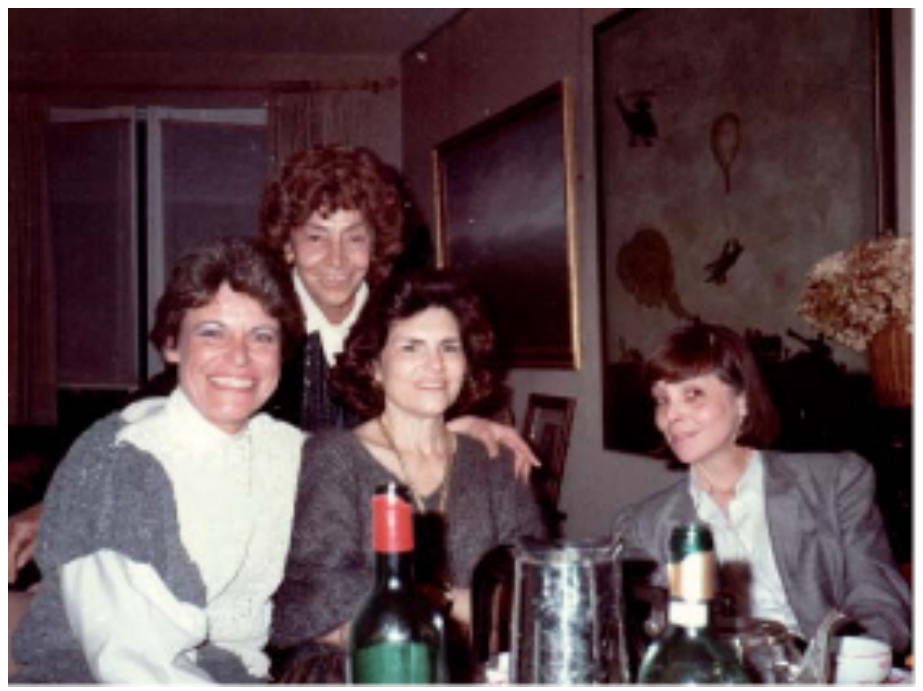

Fig. 3. De Izquierda a derecha: Gloria Delgado, Emma Reyes, Cecilia Zambrano y persona por identificar en casa de Cecilia Zambrano. París, circa 1989. Fotografía cortesía de Gloria Delgado.

\section{Generosa, amplitud mental, visión global}

Emma era considerada por sus allegados como una conversadora con una gran capacidad de oratoria y una persona generosa en extremo, tanto en sus relaciones y vida personal, así como en su producción plástica. Germán Arciniegas afirmaba que era "la madrina de cuanto pintor colombiano llega a París"," por ser quién se encargaba de recibir y ayudar a los artistas que iban a residir en la ciudad. En este mismo sentido, Plinio Apuleyo Mendoza en el libro Nuestros Pintores en París apunta al respecto:

"Los pintores que fueron llegando en las postrimerías de los años sesenta y a lo largo de los años setenta, la encontraron siempre en su camino. Ayudó a Botero a plantar su tienda en París. Darío Morales y Ana María, su esposa, veían llegar la aurora hablando con ella en su apartamento cercano al Observatoire. Caballero, Cuartas, Cogollo, Barrera, Francisco Rocca y Gloria Uribe giraron en torno suyo, recién llegados. Sí, antes de echar plumas, ellos eran los pollitos y ella la gallina"13.

Su generosidad para con sus amigos y su país, del que consideraba que no le había hecho justicia, era notable. Su relación de amistad con Maritza Uribe de Urdinola (fundadora del Museo de Arte Moderno La Tertulia, quién fue su directora y presidenta honoraria, y Gloria Delgado museógrafa e historiadora del arte, directoras ambas del Museo de Arte Moderno La Tertulia por más de 20 años) se afianzó a través de una larga y constante correspondencia epistolar. Reyes asiste y participa en diversos eventos del Museo, como la II y III Bienal de Gráficas en Cali. Y posteriormente realiza una donación al Museo debido a la admiración que les profesaba como directivas, por la gestión que realizaban en pro del arte en el país. Por su forma de ser y cercanía con artistas colombianos y de otras latitudes, Emma llega a coleccionar obras de arte de artistas que con el tiempo llegaron a ser figuras nacionales e internacionales. En entrevista con Camilo Calderón para la revista Al Día se hace evidente no sólo su generosidad sino su amplitud mental al hacer manifiesto que desea dejar como legado al país, esas adquisiciones que había logrado a lo largo de su trayectoria artística. Donación que efectivamente se concreta posteriormente con treinta dibujos, tres pinturas y un ensamblaje; $y$

\footnotetext{
${ }^{12}$ Arciniegas Germán. “Cosas de Emma Reyes”. Periódico El Tiempo. Bogotá. 20 de febrero de 1992. Recuperado el 5 de noviembre de 2014 en: http://www.eltiempo.com/archivo/documento/MAM-40478.

${ }^{13}$ Garzón, 2013: pp. 122-123.
} 


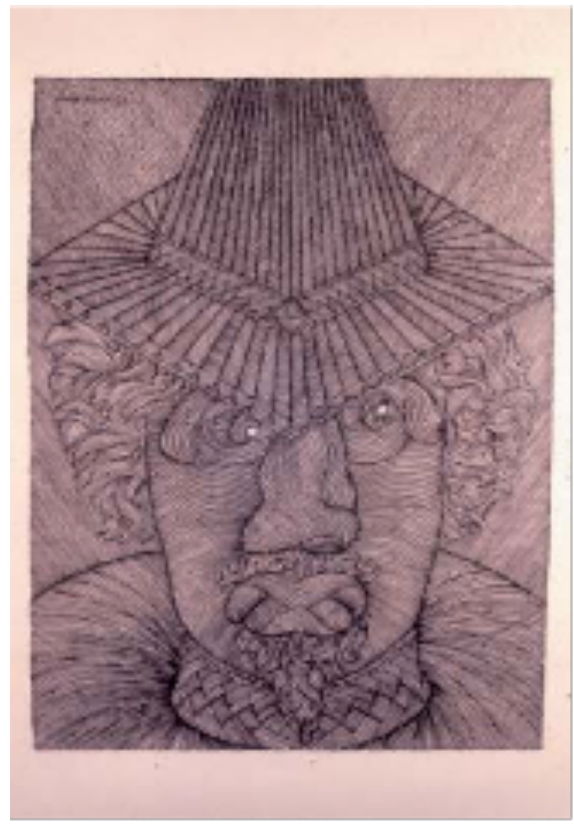

Fig. 4. Retrato No.14, 1976, Retratos imaginarios, Tinta sobre papel chitón, 71 x103 $\mathrm{cm}$. Exposición Emma Reyes. Galería Esede. Bogotá.

por otro lado, pinturas de artistas de reconocida trayectoria en el país y en el mundo. En el artículo Calderón afirma que Emma:

“[...] conserva su importante colección de pinturas, cuadros que a lo largo de su vida ha ido intercambiando con otros artistas de todo el mundo. Además, están los retratos de diferentes épocas que le han pintado los amigos, entre ellos ocho de Grau, uno de Obregón y uno de Luis Caballero. Esta colección, Emma Reyes piensa donarla al Museo de la Tertulia, de Cali, porque considera que `es la obra más respetable que se ha hecho en Colombia y porque tengo verdadera admiración por la labor discreta, elegante y efectiva que han hecho sus directivas" 14 .

En su época de mayor producción y expansión temática, Emma Reyes exhibe mayoritariamente en la ciudad de Cali, Colombia. Certámenes como la exhibición de las obras de Emma Reyes del 13 al 24 de julio de 1961 en el Museo de Arte Moderno La Tertulia, marcó su record expositivo en la ciudad. Reyes también participó en eventos tales como el XV Salón de Artistas Colombianos en Noviembre de 1963, realizado en el Museo; el Salón Austral y Colombiano de Pintura realizado en Junio de 1968, en el marco del 8o Festival Nacional de Arte de Cali y participó en la exposición (además de conformar) la Colección del Museo de Arte Moderno La Tertulia desde 1976.

Parte de su legado en pinturas y dibujos, así como correspondencia de su autoría fue donado a la Fundación Arte Vivo Otero Herrera FAVOH, cuos integrantes son colombianos residentes en Málaga, España. Y otra parte del acervo se encuentra en Francia, a través de una donación de 150 de sus obras que realizó Emma personalmente al Museo de Perigueux, que para el momento era:

“[...] el mayor depósito que en un museo, no solo de Francia sino de Europa se consagra a una artista de nuestra América. En cierto modo se explica por las vinculaciones de Emma con la ciudad de Montaigne. En los edificios más importantes de Perigueaux, Emma deja grandes murales que figuran hoy en las guías de la ciudad"15.

Esta actitud desprendida no solo reside en su capacidad de ofrecer el producto de su creación artística, para garantizar su preservación para la posteridad, dado que Emma no tuvo hijos y su trascendencia se encuentra en su obra, sino que "a Emma Reyes hay que reconocerle el mérito de ser uno de los artistas que menos se repiten en Colombia y que menos concesiones le hacen al éxito comercial"16. Como viajera incansable, el equipaje en la vida debe ser liviano para ser también

\footnotetext{
${ }^{14}$ Calderón: p. 50 .

${ }^{15}$ Arciniegas, Germán. "Emma Reyes". Periódico El Tiempo. 14 de diciembre de 1995. Recuperado el 5 de noviembre de 2014 de: http://www.eltiempo.com/archivo/documento/MAM-482823.

${ }^{16}$ Medina, 1986: p. 40.
} 
generoso consigo mismo, por ello no es extraño que diera cuenta de su necesidad de compartir aquello que había logrado en vida, desprendiéndose de ataduras banales, por esto señala:

"Quisiera llegar a tener solamente el caballete, los cuadros que estoy trabajando, mi cama y, naturalmente, los libros que me son indispensables. Todo lo demás lo he ido regalando. He adoptado el verbo descosificarse, que para mí significa botar todas las cosas Por la ventana: perversamente, yo me descosifico yle doy mis objetos a los otros para cosificar a los demás"17.

En su obra Emma es generosa con la línea, que parece interminable, de hecho, es una línea que desborda el formato, que le queda pequeño o que se expande por fuera de él, sin poder contenerlo, así como no hubiese un espacio físico en el planeta que la sujetara a ella. El crítico e historiador del arte colombiano Álvaro Medina indica alrespecto:

"En general, la línea de Emma Reyes es gruesa. En ocasiones ha sido muy fina y a veces ha llegado a ser tan ancha como la palma de la mano. La línea llena las formas y además las bordea [...] Para llenar las formas, la línea se ordena en segmentos paralelos que ondulan o se mantienen rectos cuando no giran en torno de sí mismos en espirales muy vastas y de intrincada factura. Se diría que Emma Reyes no concibe el plano como un área delimitada al exterior por una línea que podría marcar el contorno, sino como hileras de líneas paralelas en sucesión infinita"18.

Percepción que comparte el escritor colombiano Antonio Montaña, amigo cercano de Emma, cuando afirma de sus figuras, personajes, retratos y monstruos son obras que:

"He mirado una y otra vez a Emma dibujándolos: una línea que no cesa. Desciende, tuerce, se envuelve, sin dejar de correr como agua de arroyo inventando nuevos cauces. No hay aparente finalidad y por eso no extraña la ausencia de ese gesto del pintor cuando se detiene y aleja para observar desde la nueva perspectiva el avance del trabajo"19.

En este mismo sentido, se manifiestan la escritora y crítica del arte colombiana Alba Lucía Ángel y el escritor colombiano Fernando Herrera cuando plantea que son:

“[...] figuras sin bordes. Sin aristas. Personajes sin límites, que se expanden: se salen del papel, con líneas que ella traza, segura, definida, dejando sin embargo que la modulación y el ritmo marquen siempre el volumen ${ }^{20}$. [...] la pintura de Emma Reyes siempre se desborda de sus límites. Podrían ponerle el papel más grande de la tierra, y siempre pintaría un único elemento que rebasara el espacio y que quedara mutilado en alguna parte" 21 .

Esa amplitud que caracteriza su personalidad, que se hace visible en su obra con el trazo de sus líneas y formas interminables, que se repiten una y otra vez de forma sistemática y obsesiva, se extiende a un mural de 120 metros cuadrados que realiza en la nueva Biblioteca Municipal de Perigeux que:

“[...] remite inmediatamente a una sensibilidad latinoamericana. Se trata de un jardín tropical suspendido en el aire con flores iridiscentes en relieve. Quise dibujar un sueño de alegría, con un cielo azul intenso, con bellas flores y manuscritos que caen sobre nuestras cabezas [...]"22.

Otra de sus obras, reconocida como una obra poco estudiada y un tanto inédita, y que da cuenta de su necesidad de extender los límites, condensando su trabajo es:

“[...] un dibujo de 380 metros de largo que realizó en 1974 y que fue quedando enrollado a medida que la ejecución avanzaba. Es la mejor explicación porque la cadena de variaciones modulares que podemos ver cada vez que nos paramos delante de uno solo de sus dibujos de hoy (en verdad, sus pinturas son elaboradísimos dibujos) guardan relación con de las que

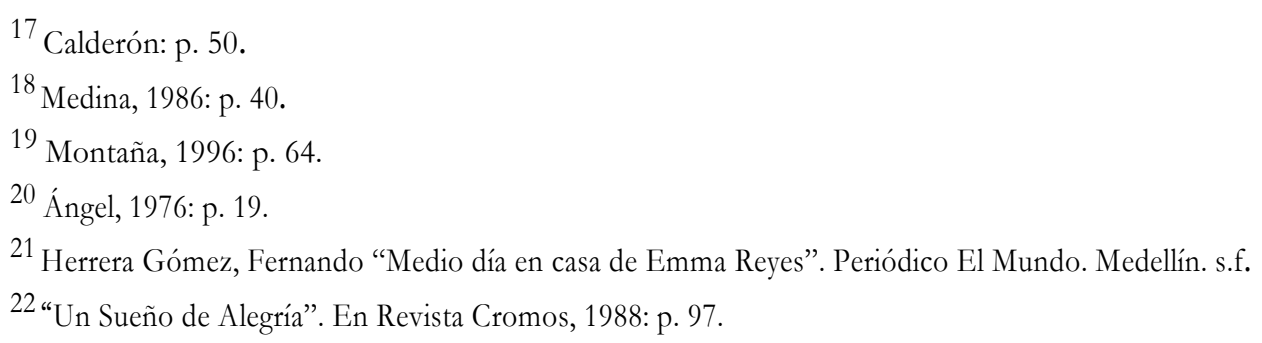


podemos observar cuando se hala el rollo y el papel nos ofrece tres o cuatro palmos de ordenados trazos que muestran las infinitas posibilidades de un cuadrado",23.

Adicionalmente, esa misma amplitud se refleja en que no sólo extendía las fronteras del espacio pictórico al máximo, también extendía sus propias fronteras como viajera incansable, dispuesta siempre con entusiasmo a una nueva aventura. De ello da cuenta ella misma en un texto que publica la revista El Aleph.

"Yo preparaba mi regreso a Europa, porque de Italia me pidieron que fuera a hacer dos murales en una villa privada de la isla de Capri; me pagaban los pasajes y además por sentirme devorada por la pasión de querer estar en todos los sitios, mucho más si eran bellos, acepte sin dudarlo ni un minuto. Pensé, por otra parte, que tendría tiempo de volver a México"24.

\title{
Atenta, concentra
}

Su disciplina y concentración se revelan a través de un trabajo constante, arduo y sin interrupciones, que recicla formas, figuras, personajes. En entrevista para la revista Al Día con Camilo Calderón titulada Emma Reyes trajo su exposición de París, indica "[...] pinto de seguido hasta las 8 de la noche. A esa hora, regularmente tengo comidas o invitaciones con artistas y amigos; siempre trato de no hacer compromisos de día, porque es tiempo sagrado para mi trabajo" ${ }^{25}$. En su obra es cuidadosa y atenta, lo anuncia una línea meticulosa, que

\begin{abstract}
“[...] delimita, pero también construye volúmenes y texturas rellenando los espacios o fragmentos con líneas paralelas muy cercanas, de una factura que denota minuciosidad. Estas líneas paralelas de relleno están siempre presentes en su obra y ayudan a conformar volúmenes en hojas, músculos del rostro, movimiento en las manos, plumas y texturas en las pieles de los diferentes motivos que emplea. Las líneas de conformación del dibujo siempre están visibles, a pesar de que se encuentren debajo de capas de color. Las líneas de relleno también son producidas a través del uso de una cantidad de óleo o tinta que empasta la superficie y genera patrones con la pincelada. Usa colores de base en grandes superficies para sobreponer líneas paralelas en otro color, generalmente contrastante, que rellenan la forma creando la sensación de volumen y movimiento a través de ello" 26.
\end{abstract}

\section{Creativa}

Gabriela Arciniegas, hija de Germán Arciniegas, cuenta que Emma Reyes tenía la habilidad de transformar elementos simples en objetos sofisticados, y como ejemplo de ello señala que era capaz de convertir con algunos detalles el vestido más sencillo en uno que luciera refinado. Parte de su formación en el convento estaba conformada por la experticia en costura y bordado, que se concretaban en dechados con múltiples posibilidades en la puntada, forma y color. Disfrutaba la innovación que lograba con gran imaginación y cambios sutiles, lo que se refleja en su obra en el tratamiento de la línea cuando retoma elementos, figuras o personajes con el fin de lograr evolución en la imagen y producir una nueva. La intención es desplegar la imagen hasta sus infinitas posibilidades, "[...] un dechado realizado con experticia, en el que teje una huella de sí misma, lo que la hace coherente y consistente en toda su producción plástica" 27 . Por esto, es habitual encontrar en diferentes épocas obras con cierto grado de similitud, ejemplo de ello son las series de los monstruos y los retratos imaginarios, de las que hay una enorme cantidad de dibujos con diferencias en el color, variación en la línea y la forma, que obedecen fundamentalmente a una misma idea. Una serie que nunca logra concluir, un dibujo automático como un dechado que se encuentra en continua evolución por sus múltiples posibilidades. En este sentido, Emma indica:

\footnotetext{
23 Medina, 1986: p. 41.

${ }^{24}$ Reyes, 2000: p. 10

${ }^{25}$ Calderón, Camilo. "Emma Reyes trajo su exposición de París”. Revista Al día. s.f. p. 50.

${ }^{26}$ Vergel, María del Pilar (2014): "Panorámica de una línea perpetua: Tres momentos en la obra de Emma Reyes" en Cajones y Dechados: Memoria, vida y Obra de Emma Reyes. Libro en proceso de edición. Editorial Pontificia Universidad Javeriana, Cali. 2014, p. 26.

27 Ibíd. p. 27.
} 
"Empecé como autodidacta, hice clasicismo, he hecho figura humana, paisaje, pintura abstracta y collage de objetos. Pero no encuentro contradicciones en mi obra, pienso que en conjunto tiene una unidad: hay cambios de materiales, de temas, hasta de escritura, pero hay siempre el mismo espíritu de trabajo obsesivo sobre unos mismos elementos, que se repiten en el interior de la forma principal"28

Antonio Montaña apunta que a pesar de que su obra está unida por elementos formales que se reciclan, estos logran originalidad a través del carácter propio que les imprime:

"Cuando los "monstruos salieron al mundo de las galerías con la mitológica barba coloreada con tonos audaces se habían integrado ya la forma y el color. En los paisajes de Israel bulle la misma idea que generó los "Monstruos" y aunque por mesura y tranquilidad sean diversos los une, en su variación un estilo. $\mathrm{Y}$ un estilo profundamente personal en el que será bien difícil encontrar influencias. Un estilo, para ser conciso original" 29.

Estas mutaciones o transformaciones también se hacen evidentes en su obra en las variaciones de color que denotan diferencias entre el espíritu del trópico, agreste, desordenado y vibrante propio de su cultura, frente al paisaje europeo, ordenado, cargado de colores fríos y agrisados que es donde se desarrolla como artista. "Para el pintor colombiano Gregorio Cuartas, [...] la pintura de Emma tiene mimetizarse en el dicotómico mundo en el que despliega su obra",30. Cuartas asevera sobre su pintura que:

"Es una pintura muy propia, suramericana. Cuando ella pinta óleo o acrílico tiene un colorido distinto, mientras que cuando trabaja sobre papel [...] es un colorido muy fino, muy refinado, su componente europeo. Es lo que les pasa a todos los pintores latinoamericanos cuando llegan aquí, se van apaciguando en el color y en todo, se les va perdiendo lo brutal nuestro, el medio ambiente influye y uno se va mimetizando" 31 .

\section{Excelente comunicación, fluidez verbal}

La excelente comunicación y fluidez verbal de Emma Reyes es indudable. En todas las entrevistas, quienes la reseñan dan fe de su agradable conversación y agudeza mental. Por otro lado, sus amigos, la pintora colombiana Teresa Cuellar, el crítico e historiador del arte colombiano Álvaro Medina, la directora de la Galería el Callejón, Lili de Ungar y Gabriela Arciniegas, hija de Germán Arciniegas manifiestan que además de ser el centro de atención por sus interesantes narraciones y anécdotas, las conversaciones con ella eran interminables por su fascinante personalidad, y adicionalmente, por aquello que está detrás de su historia, una mujer huérfana que sale de un hospicio y que logra con su ingenio, creatividad y capacidad de adaptación, superar su condición.

Antonio Montaña señala en un artículo para el periódico El Tiempo que era tan conocida que uno podía encontrar referencias de ella en la calle de la siguiente manera:

“¿Conoce usted a una pintora colombiana, Emma Reyes, que pasó aquí algunos años y que en París vivía con una muerta?' O era algún pintor el que contaba: 'Con Emma puede unos pasar los días enteros hablando y jamás cansa. Puede conversar de pintura, o de mundanidad y ella siempre tiene algo inteligente que decir'. O también, por qué no, era un turista el que exclamaba: 'Emma Reyes es la mejor guía de Roma que alguien pueda conseguir'"32.

Para Alba Lucía Ángel, "Emma tiene el don de penetrar más allá de palabras, con la simpleza de quien ya sabe muchas cosas, ha visto mundos, recorrido las trochas y los mares, pues es viajera

\footnotetext{
28 Calderón, Camilo. "Emma Reyes trajo su exposición de París”. Revista Al día. s.f. pág. 49.

${ }^{29}$ Montaña, 1960: p. 5.

${ }^{30}$ Vergel, María del Pilar (2014): "Panorámica de una línea perpetua: Tres momentos en la obra de Emma Reyes" en Cajones y Dechados: Memoria, vida y Obra de Emma Reyes. Libro en proceso de edición. Editorial Pontificia Universidad Javeriana, Cali, p. 28.

31 Penilla Céspedes, 1991: p. 13.

${ }^{32}$ Montaña, 1960: p. 5.
} 


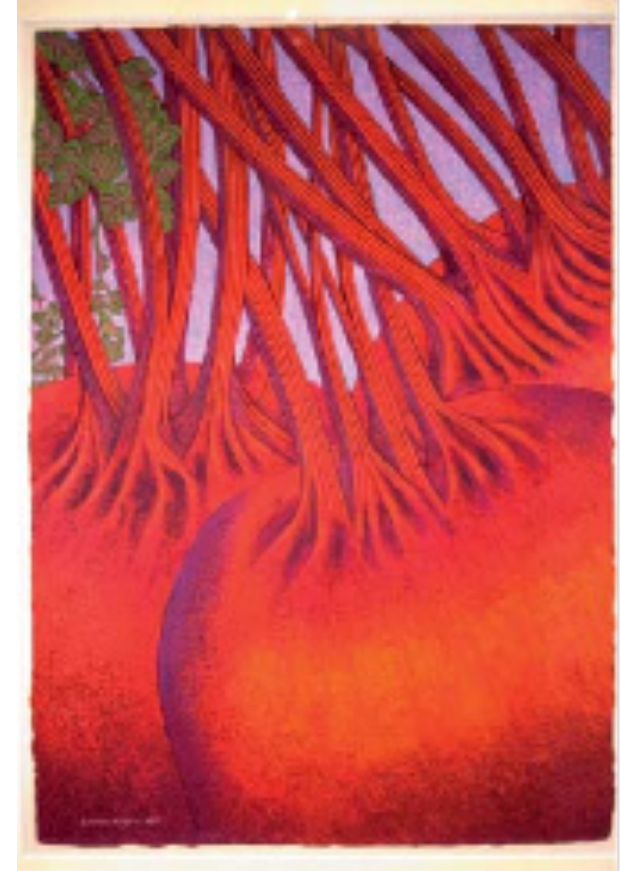

Fig. 5. Sin Titulo, 1983, Serie Legumbres, Gouache sobre papel baker, $71 \mathrm{x}$ 100 cms. osición Alexis Gorodine. Galería Garcés Velásquez. Bogotá.

infatigable" ${ }^{33}$. Los relatos de su vida novelada, contados por ella misma, son tan interesantes e increíbles, que causa curiosidad entre quienes no la conocen, construyendo un mito que la acompañaría hasta el final de sus días.

"Ya en Buenos Aires había escuchado su maravillosa aventura. Allí algunos amigos referían los hechos increíbles de su vida — todos los hechos de la vida de Emma Reyes parecen increíbles- y aún se asombran como quien relata las hazañas ${ }^{34}$ de un fantasma. [...] La historia de Emma reyes se desarrolla vertiginosamente. Cada mes es una novela, cada nueva ciudad otra gran conquista del $\operatorname{azar}^{35}$.

Estos relatos propios de su fluidez verbal y una gran capacidad oratoria, se trasladan a la escritura. Inicia y continua el hábito epistolar incentivada por Arciniegas, quien le propone escribir un libro con ellas, con la promesa de que guardaría estas cartas en un baúl.

"Emma comenzó a escribir las cartas con todas sus memorias, partiendo desde el primer lejano recuerdo de su infancia, cuando a los dos años y medio se cayó de una silla. [...] Durante muchas noches hurgó todo su pasado, y fue escribiendo las cartas que en la casa de su amigo se iban amontonando en el baú1. Sucedió que un día comenzaron a llegar los elogiosos comentarios de sus amigos escritores: García Márquez le proponía editarlas. Miguel Ángel Asturias le escribía maravillado por su escritura vigorosa, y la llamaba colega. Manuel Scorza la felicitaba. Germán Arciniegas, entusiasmado, no había podido guardar en silencio toda la correspondencia, y había roto el pacto al dejar leer las cartas" 36 .

Necesidad de expandirse, trataba de frenar su tren de vida y no le era posible.

De acuerdo a sus narraciones en Memorias por Correspondencia, libro publicado en el 2012 en el que Reyes le describe a Germán Arciniegas su infancia en 23 cartas escritas en casi una década, se narra con total desenfado una vida llena de aventuras, con pasajes de privaciones, unos amargos y otros divertidos. Cuenta el abandono del que fueron objeto ella y su hermana, así como su vida en el convento y como se escapa un día que encuentra la puerta abierta. En 1976 en el programa de televisión Gloria 9.30, Emma relata sobre su infancia en entrevista con Gloria Valencia de Castaño:

\footnotetext{
33 Ángel, 1976: p. 19.

34 sic.

35 Pérez, 1950: p. 11.

${ }^{36}$ Herrera Gómez, Fernando “Medio día en casa de Emma Reyes". Periódico El Mundo. Medellín. s.f.
} 
"Emma, ¿cómo fue tu infancia?

A veces me parece tristísima, a veces me parece privilegiada. Eso es muy ambiguo, concretemos: ¿Cómo fue tu infancia?

Esa infancia se pasó en un convento sin salir nunca. En un mundo absolutamente de sueño, de abstracción, porque todo lo que pasaba fuera del convento lo denominábamos `el mundo', como si estuviéramos en otro planeta. Naturalmente eso desarrollo en nosotras una enorme imaginación, nuestra imaginación se enloqueció imaginándonos inclusive que los arboles eran de otro color y la gente de otra forma, y fue tal la angustia de lo que estaba afuera que yo decidí escaparme un día". [...] "¿Quién te dio afecto en esa infancia?

No creo que tuviéramos ese tipo de preocupación, lo nuestro era el pecado, salvar el alma, no ser malas, tenerle miedo al diablo..." "Salí con el uniforme que tenía puesto y todo eso pasa en mi mente como un sueño, hasta que llego a un tren al que prácticamente me fuerzan a subir, y todo era tan irreal, porque nunca había visto un tren un tranvía, un automóvil, te puedes figurar si uno tiene una descripción de esas cosas".

"¿Y allí estudiabas algo?

No, eso era voluntario, los que querían leer o escribir, los domingos tenían una clase.

¿Y tú aprendiste?

No, yo no vi la necesidad, ¿para qué?

¿Entonces cuando saliste del convento no sabías leer ni escribir? No, nada, absolutamente" 37 .

"El mundo" como ella le decía a lo que existía fuera de las paredes del hospicio, la recibió el día que salió a él, ese mundo le quedó pequeño desde ese mismo día, como reseñan los siguientes autores:

“[...] sintió la necesidad de salir del país, "simplemente porque creí que aquí no tenía porvenir; fue algo instintivo, espontáneo, con una sed infinita de conocer todo, de verlo todo, con una enorme vitalidad que me ha servido mucho, con una curiosidad insaciable y un gran amor por el ser humano; salí, como viajan los jóvenes de hoy, sin un plan, sin itinerario fijo, sin saber si uno va a ganar o perder, pero con un espíritu de disponibilidad que imagino necesario cuando uno se lanza a una vida así". Recorrió toda la América del Sur viajando por tierra, de pueblo en pueblo, hasta llegar a Buenos Aires [...]"38.

"[...] Salió de Bogotá sin más experiencia que la de una recogida en el hospicio, experta en dechados de costura. Y emprendió un viaje que paró en Buenos Aires, marchando a pie, en buses, trenes o lo que fuera, vendiendo cajas de Emulsión de Scott. De Buenos Aires pasó a Montevideo en plena guerra del Chaco, pasó la luna de miel en un garaje, se fue a vivir a la selva del Paraguay y los guerrilleros le asesinaron el hijo en una escena de crueldad infinita. En Buenos Aires pintando se ganó un concurso internacional y fue a dar a París [...]"39.

"América del Sur, a pie, prácticamente, cuando ni carreteras existían. Yo era más pobre que una rata y aprendí a subsistir chiquita a punta del ingenio. Cuando pedí que me ayudaran me contestaron con cajas destempladas, (...), y luego de unos años de aprender caminando, mirando, compartiendo vivencias con toda clase de gentes, haciendo mil oficios, me comenzó la picazón de la pintura" 40

"De Francia se fue a Italia, donde vivió inmersa en el aire romano, en el arte barroco y bizantino de la ciudad pagana y allí encontró a De Chirico, a Moravia, Giacometti, Fontana, se hizo amiga de todos: de los hippies de entonces, de los príncipes. y así por toda Europa; porque Emma Reyes no da abasto cuándo bota corriente" 41 .

\section{Autoritarismo, voluntad de poder y de ejercer mando}

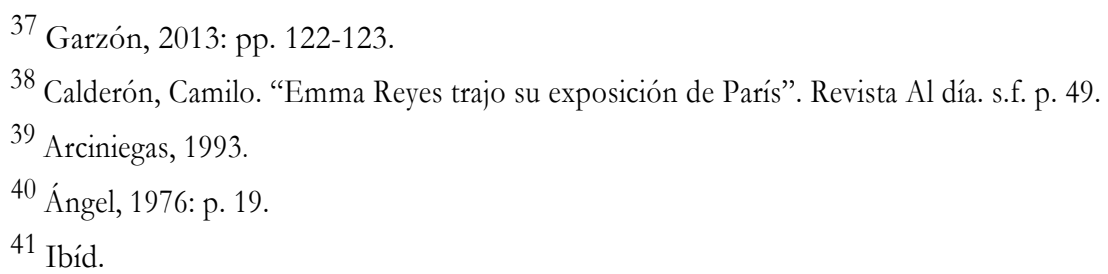


Su capacidad natural para sobreponerse a las circunstancias y tomar el control de las situaciones, aunado a una personalidad férrea pero encantadora, construyen un halo sobre todo lo que la rodea, lo que deviene en el mito de Emma Reyes. Ese mito la antecedería y continuaría siendo la forma de recordarla después de su muerte. El culto a su personalidad convertida casi en leyenda, es evidente en los escritos que la reseñan, no sucede esto en su pintura, particularidad de la que ella se sentía responsable y también lamentaba. La crítica del arte Martha Traba, en relación a su personalidad, afirma que:

"Es difícil hablar de Emma Reyes. Los innumerables comentarios periodísticos aparecidos sobre ella (raramente sobre sus cuadros), tienen la extraña y temible condición inapelable de los dogmas. A través de ellos se establecía, con entusiasta unanimidad, el dogma de la personalidad de Emma Reyes. [...] La personalidad de Emma Reyes ha pospuesto el análisis de sus cuadros: el gran público conducido hábilmente, demostró una vez más su fácil emotividad y su falta de espíritu crítico. Pero su personalidad no puede ponerse en duda [...." ${ }^{\prime \prime 2}$.

Traba, a pesar de su postura frente a su personalidad dogmática, al referirse a su trabajo artístico parece también enunciar aspectos más propios de la personalidad de Emma, es así como se ve su capacidad de influenciar a los demás imponiendo sus ideas y conceptos.

"[...] Pero esa personalidad no se puede poner en duda. Sus obras la acusan con tanta violencia como simplicidad; se lee en ellas, a primera vista, su espíritu directo, su fortaleza de visión, su claridad conceptual, su inequívoca voluntad de reducir el universo de las formas a un esquema claro y enérgico"43.

Luis Caballero confirma 20 años después de la reseña de Traba que el peso de su personalidad disminuye la atención sobre su pintura, siendo indudable que esto sucede porque el mito de Emma nace a través de su vida, no de su producción artística.

"Hay pintores míticos. De leyenda. De los que se habla, en torno a quienes se tejen y destejen anécdotas, pero cuya pintura se ignora. Emma Reyes es uno de ellos. Su enorme personalidad impide que se vea su obra para desventura de quienes en verdad aman la pintura. [...] La leyenda de Emma se ha logrado a partir de su propia vida, a pesar de su obra; es por esto que tal vez su obra es ignorada [...]"44.

Capacidad de influenciar a los demás, imponiendo sus ideas y conceptos.

Reyes fue autodidacta, uno de sus primeros maestros formales fue el artista francés André Lothé en París, quien la impulsaría a seguir por fuera del academicismo por su clara tendencia a seguir los dictados de su propio instinto y estética, imponiendo sus ideas y conceptos sobre el arte, "sin recibir la directa influencia de los grandes maestros contemporáneos". Esta particularidad se ve reflejada en su obra, la cual se construye a partir de la confianza y seguridad en sí misma y en sus decisiones, a pesar de la influencia que puede tener del entorno en el que la desarrolló. En este sentido, en un artículo de 1952 se señala que:

"No niega Emma Reyes que las tendencias y las preocupaciones de la pintura mexicana actual la sugestionan e influyen, pero tiene fe en su personalidad y cree que pueden favorecerla, pero nunca perjudicarla en la consecución distintiva de su obra" 45

Esa personalidad encantadora, fuerza y capacidad de dirigir su propio destino, la llevan a lograr todas sus metas, es así como consigue su primer atelier en París, en un lugar exclusivo en la postguerra, por un precio irrisorio, con una particularidad en contraprestación: la de cuidar una momia. Al respecto, su amigo, el pintor barcelonés Alejo Vidal Quadras le dice "tú, la analfabeta de Colombia, todo lo que deseas lo obtienes, y no se puede decir que con grandes esfuerzos o sacrificios" " Impulsada por Lothé, posteriormente inaugura su primera exposición en París en la

\footnotetext{
42 Traba, 1993.

43 Ibíd.

${ }^{44}$ Caballero, 1996: p. 32.

45 “Regreso a los Orígenes”. Periódico El Tiempo. Bogotá. 17 de Octubre de 1952.

${ }^{46}$ Reyes, 2000: pp. 84-85.
} 
Galería Kleber, después de una exposición de Paul Gauguin, donde la prensa la registra y presenta con gran exotismo. A través de sus reseñas y los comentarios de sus conocidos, se percibe que efectivamente por sus cualidades naturales, Reyes poseía un singularidad que iba más allá de la visión eurocentrista con relación a Latinoamérica.

"El martes 1 de marzo se inauguró como fue profusamente anunciado por la prensa y los noticieros cinematográficos de París, la exposición de 50 lienzos de una extraña pintora "pielroja", descubierta por dos periodistas franceses en el Gran Chaco, en el corazón de Suramérica [...] La Pielroja resulto ser una colombiana: Emma Reyes de Botero, nacida en Boyacá. "Es una pielroja auténtica", insiste el imaginativo diario parisino: "una india chibcha, cuya raza, prima-hermana de la de los aztecas, no cuenta en la realidad más que con 3.000 representantes [...] El que las galerías Kleber la hayan escogido para suceder a Gauguin, a quien se alcanza a parecer por el aspecto un tanto exótico de sus motivos [...]”"47.

Reyes se relaciona fácilmente por su carisma y su extroversión. En el viaje a México que realiza de 1951 a 1953, conoce a los pintores mexicanos revolucionarios, a Frida Khalo, Diego Rivera y a la fotógrafa Lola Álvarez Bravo. Consigue trabajar para Rivera en oficios varios en los murales y con Álvarez Bravo en su Galería de Arte Contemporáneo, ayudándole en la organización de la última exposición de Frida Khalo que se realizó por encargo de Rivera, así como en una serie de exposiciones en diferentes ciudades del país, donde ella misma hace gala de su determinación:

“[...] Como Lola me ayudaba a mí, yo me le ofrecí para organizar unas exposiciones de los grandes pintores mexicanos, a quienes en las provincias desconocían. Le pareció muy buena mi idea, pero me dijo que le aburrían los viajes y la organización. En consecuencia asumí tanto la organización como aquello de pelearme tal vez con los gobernadores para que aceptaran el proyecto y pagaran el mínimo de los gastos de transporte de la obra y mi alojamiento, así como los costos de uno o dos ayudantes, ya que sola era incapaz de asumir el montaje de una exposición de tal naturaleza [...] viaje con los cuadro y montaba toda la exposición; cuando Lola llegaba apenas tenía que participar en el acto de inauguración" ${ }^{\prime 8}$.

\section{Consecuencia entre lo que pensaba y hacía.}

Emma Reyes era realista ante la lectura que tenía el medio y el público de ella y su obra. "Maritza querida, como ves, el nomadismo continua [...]". Esta cita corresponde a las primeras líneas de la carta dirigida por Emma a Maritza Uribe de Urdinola. Las líneas siguientes que completan el primer párrafo muestran a una mujer que ante todo, ha valorado la vida y desde la escritura y la grafía ha manifestado sus mayores potencias:

"[...] Dejé París y he venido a instalarme con Jean (Perromat, su esposo) ha Bordeaux. Compramos una casa que no es la ideal, ni la casa de mis sueños, pero tal vez mejor, porque si uno tiene la casa de sus sueños tiene la casa y no le quedan los sueños, que al final es lo mejor de la vida, porque nos sirven de motor y estímulo" 4 .

Como autodidacta, la vida y obra de Reyes están emparentadas, ella pinta lo que la sensibiliza, ve, conoce, lee, fundamentalmente su interés está basado en el ser humano. Su gran capacidad para relacionarse la lleva a interesarse por la condición humana primordialmente. En su pintura, toda su obra esta permeada de esta condición. Sus paisajes, monstruos, retratos, frutas, flores y legumbres, están cargados de una simbiosis entre la naturaleza y lo humano que están en permanente cambio y evolución:

"El motivo de mi paleta es el ser humano. El paisaje se encuentra dentro del ser humano. Y por eso el hombre tiene el color del paisaje, el paisaje de mi país, el colorido fuerte del trópico. El hombre lleva impreso ese color local; pero junto con este, también los colores y las angustias del hombre universal, que es no solamente el indígena de las tierras del Nuevo Continente, sino

\footnotetext{
47 “La Pielroja Boyacense”. Revista Semana. 5 de marzo de 1949.

48 Reyes, 2000: pp. 99-100.

49 Carta de Emma Reyes dirigida a Maritza Uribe de Urdinola. Burdeaux, Diciembre 13 de 1985.
} 
también el hombre cansado, solitario y sin esperanza que vive en el ambiente de la técnica y el refinamiento de nuestro siglo" 50 .

“[... mi pintura está inspirada en la humanidad porque mis personajes han estado basados siempre en gente que conozco, sobre la que he leído, porque yo en realidad he gastado más tiempo estando con la gente que pintando: y no en función social, de salón, me anota con viveza, porque me ocupo de ellos, de estarles cerca para entender al máximo" 51.

"Al público le interesa siempre más la historia de la persona, banal o no banal; yo he sido una víctima de ese interés y por eso he llegado a pensar que el enemigo de mi obra es mi propia vida, no importa las experiencias extraordinarias que haya tenido. La verdad es que la obra se ha hecho con esas experiencias: Sí, mi obra se parece a mi vida. Como he cambiado tantas veces de sitio, como he pasado por vivencias tan diversas, mi obra también ha tenido numerosos cambios y ha pasado por todo" 52 .

\section{Melancólica}

La nostalgia es transversal en la obra de nuestra artista, que siempre anheló ser reconocida en su país de la misma manera que se lo era en el exterior. Al respecto en entrevista con Olga Lucía Cárdenas, Reyes afirma que "quisiera saber por qué no me perdonan que me haya radicado en Francia, si llevo a mi país en la

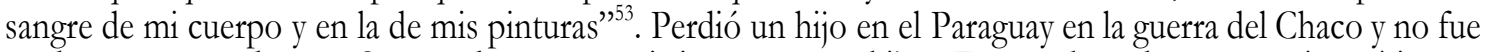
madre por segunda vez. Sus cuadros se convirtieron en sus hijos. En su obra, de manera sistemática, se encuentran maternidades sin nombre que desarrolla en diversos dibujos y pinturas:

"El marido se inclinó más a la aventura bélica que al bohío. Era un rojo guerrillero. La mujer quedó sola en una de esas escenas sin nombre que produce hoy la barbarie universal, llegaron los soldados hambrientos a la casa y clavaron al niño con las bayonetas. Emma Reyes sin nombre, sin hijo, con un pasado tremendo a las espaldas, se marchó a Buenos Aires" ${ }^{54}$.

"Sus obras tienen rostro pero nunca un nombre. No necesita modelos. Trabaja inspirada en la vibración de sus sentimientos y en la evocación de los recuerdos. La tristeza, la alegría, la nostalgia es lo que más influye en mis cuadros. Trabajo con la memoria, pero también invento y les doy un toque personal a mis 'hijos', a mis obras. Porque nunca fui madre, pero el fruto de mi labor, cada una de mis Pinturas, son como ese bebé que se lleva en las entrañas" 55 .

"La pintura de Emma Reyes está estrechamente emparentada con el Jazz, este otro arte tan típicamente americano. Ella es igualmente violenta, libre 'o liberada' melancólica y agitada; ella es a la vez lírica y delicada, brutal y angustiosa. Ella y su magia, su color, su encanto" ${ }_{56}$.

\section{Conflicto con su procedencia familiar, no le gustaba que la identificaran con su familia.}

El halo de misterio sobre el origen familiar de Emma Reyes se refuerza constantemente al no poder identificar ningún familiar o doliente en sus primeros años de vida, no más que una hermana que la acompaña en un hospicio hasta la adolescencia y que se volverían a encontrar en la adultez, cuando Emma se casa por primera vez en el Cono Sur, con el escultor colombiano Guillermo Botero- Gutiérrez. A partir de allí, sus amigos son su familia, siendo Germán Arciniegas la figura paterna y filial más cercana de su vida, y sería a quien le confiaría sus secretos en las cartas que él mismo le alienta a escribir en la década del sesenta, y que en el 2012 fueron publicadas 23 de ellas, cumpliendo la voluntad de Emma, (si en algún momento dicho proyecto se cristalizaría, lo cual ocurrió gracias a los familiares de Arciniegas y a la Fundación Arte Vivo Otero Herrera, entidad residente aún en Málaga, España, quienes cuentan con el Fondo más amplio y vasto de Reyes a la fecha); Emma en vida quiso que las ganancias de esa "publicación futura" se convirtieran en apoyos económicos para 1993.

${ }^{50}$ Porat, M. "La Pintora Emma Reyes en Jerusalén”. Periódico Menorah, febrero de 1958. Catálogo del Museo de La Tertulia

51 Ángel, 1976,: p. 19.

52 Calderón, Camilo. "Emma Reyes trajo su exposición de París”. Revista Al día. s.f. pp. 48-49.

53 Cárdenas, Olga Lucía. "Emma Reyes Pinceladas de Nostalgia”. Revista Carrusel. p. 9.

54 Ruiz, 1999: p. 24.

55 Cárdenas, Olga Lucía. "Emma Reyes Pinceladas de Nostalgia". Revista Carrusel. p. 8.

56 Janco, 1993. 

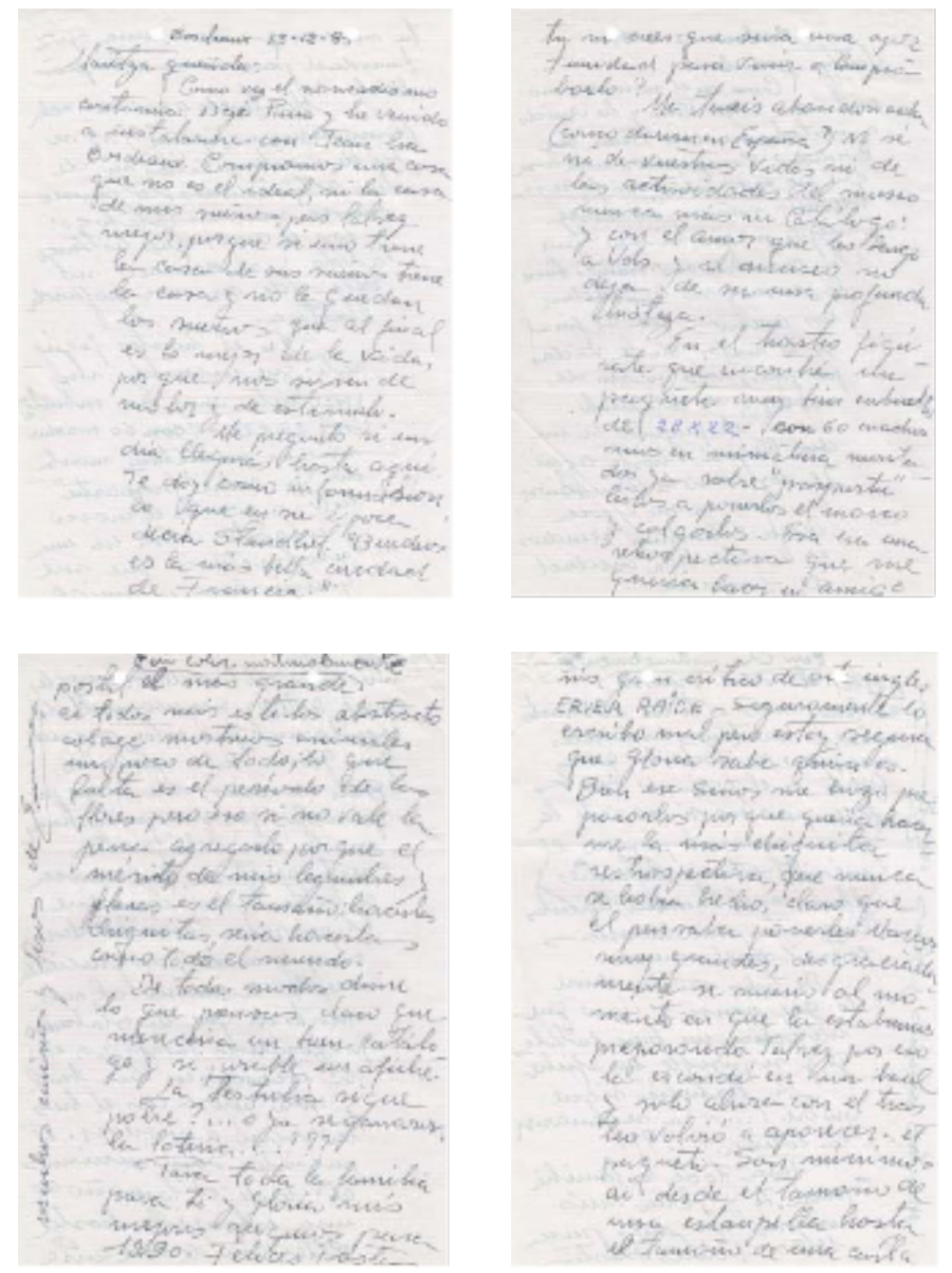

Fig. 6. Carta de Emma Reyes dirigida a Maritza Uribe de Urdinola. Burdeaux, Diciembre 13 de 1985. 4 páginas. Fotografía cortesía Centro de Documentación. Museo de Arte Moderno La Tertulia, Cali, Colombia.

la Fundación Hogar San Mauricio, quizás con el ánimo de corresponder a ese origen anónimo y cargado de historias posibles del origen de una artista cautivadora por su vida. Contribuyendo al interés del mito o quizás frente a una posible realidad de su origen, a Reyes se le vinculó en algún momento con el abolengo Reyes, proveniente de la cimiente de la familia del presidente Rafael Reyes. Este dato ha sido parte del mito de una niña que creció al margen de su origen por su misma condición de "hija natural" (hijos "por fuera" del matrimonio), hijos que por costumbre se dejaban en manos de tutores, criadas, conventos y orfanatos.

"Helena me dijo: 'Si tú hablas de la Sra. María yo te pego'. Y ese silencio duró veinte años, ni en público ni en privado volvimos nunca a pronunciar su nombre ni a hablar de los años pasados con ella, ni de Guateque, ni de Eduardo, ni del niño, de Betzabé. Nuestra vida empezaba en el convento y ninguna de las dos traicionó jamás ese secreto", escribe Emma en el libro. Y así fue. Nunca habló de la señorita María, quien aparece en el libro como su acudiente, como una especie de mamá que compartía con su hermana, pero a la cual no llamó nunca

'mamá : solo 'la señorita María'. Pero ese secreto que quiso guardar para siempre fue el que más quisieron develar sus allegados cada vez que narraba su vida: ¿de quién era hija Emma Reyes? El pintor Ramiro Arango, radicado en París con Edilma, su esposa, y gran amigo de Emma 
hasta su muerte, me cuenta por teléfono que un día coincidieron en una reunión con el escritor Manuel Mejía Vallejo, quien, haciendo pública una sospecha que tenía, le preguntó:

¿Es cierto que tú eres nieta del presidente Rafael Reyes? Yo de eso no hablo. Cambiemos de tema por favor, respondió ofuscada como pocas veces. Durante muchos años en París optó por no hablar de su pasado. No sabía cómo podría ser la reacción de Jean y su familia, una familia tradicional y reconocida en Francia. Por eso, prefirió que el libro con sus cartas se publicara después de su muerte. De hecho hoy, tanto Sophie y Xavier Perromat, sobrinos de Jean, me dicen desde Francia que no sabían nada de lo que cuenta el libro. Ni siquiera oyeron jamás de su hermana Helena"57.

Las siguientes citas hacen gala de su generosidad y respuesta ante las situaciones más atípicas de la cotidianidad, y como a partir de esa singularidad en su día a día, Emma vivió en correspondencia con un contexto al que quiso pertenecer y responder con consecuencia y responsabilidad, pero que no le fue posible tanto como hubiera querido: esa relación con Colombia y América Latina que fue tan distante, pero a la vez tan estrecha desde sus amigos y su obra, fuente y puente de todo vínculo con sus raíces.

Finura intelectual.

"Francia acaba de otorgar a Emma Reyes el grado de Caballero de la Orden de Artes y Letras. Esta distinción, que sorprende a Emma cuando Colombia apenas si tiene en cuenta a esta mujer excepcional que durante medio siglo le ha abierto las puertas de París a los estudiantes de Colombia que han llegado a la aventura como ha sido la tradición en cuantos buscan en la capital francesa su iniciación en el arte universal" 58.

Necesidad de dar y sentir afecto

"En 50 años de actividad pictórica no he recibido nada. Un día recibí en París una carta de un organismo del gobierno colombiano donde me informaban que había sido elegida para participar en el aniversario del décimo año del gobierno de Pinochet. Me precipité y tomé tres telas blancas y en el centro, sin haber pintado nada, con tinta china negra, escribí: Regularmente pinto flores. Pero donde no hay libertad no hay flores, Firmado. 'Emma Reyes. Una noche tocó a mi puerta un grupo de seis personas con un ramo de flores y vino. Eran exiliados chilenos que habían sido informados de mi gesto, secretamente, porque los tres cuadros nunca fueron expuestos. Esta historia es el único 'honor' que me ha hecho Colombia”. [...] He dado a Colombia todo lo que he logrado hacer por mí misma. Lo he dado por todos los caminos a donde mi destino me ha llevado y haciendo lo mejor posible para que mi país y yo no quedemos más mal de lo que ya se conoce" 59 .

El proyecto "Cajones y Dechados: Memoria, Vida y Obra de Emma Reyes" Registro Institucional RII 020100349 Pontificia Universidad Javeriana Cali tiene como objetivo realizar una investigación monográfica que establezca una revisión periódica de la producción artística y el acervo documental de la artista bogotana Emma Reyes (Bogotá, 1919 - Burdeos, 2003), a través del registro y catalogación de su obra depositada en tres instituciones culturales de Colombia y España, como el Museo de Arte Moderno La Tertulia de Cali, la Fundación Arte Vivo Otero (Málaga, España) y la Colección de la Biblioteca Luis Ángel Arango del Banco de la República en Bogotá. Todo este esfuerzo con el fin de realizar una monografía de la artista, contribuyendo de esta manera a los vacíos historiográficos del arte colombiano.

\footnotetext{
${ }^{57}$ Garzón, 2013, pp. 122-123.

58 Arciniegas, 1996: p. 5.

${ }^{59}$ Mackensie, Eduardo. "Soy una Obrera del Arte”. Periódico El Espectador. Bogotá. 22 de octubre de 1998.
} 


\section{Bibliografía}

Ángel, A.L: "Emma Reyes Primer Plano para un Retrato Imaginario". Periódico El País. Cali:13 de mayo. . (1976), p. 19.

Arciniegas, G. (1992): “Cosas de Emma Reyes”. Periódico El Tiempo. Bogotá. 20 de febrero de 1992. Recuperado el 5 de noviembre de 2014 en: http://www. eltiempo.com/archivo/documento/MAM-40478, (1992)

Arciniegas, G.: "De Flora Tristán a Emma Reyes”. Periódico El Tiempo. Bogotá. 9 de agosto. (1993).

Arciniegas, G.: "Emma Reyes". Periódico El Tiempo. 14 de diciembre. Recuperado el 5 de noviembre de 2014 de: [http://www.eltiempo.com/archivo/ documento/MAM-482823], (1995)

Arciniegas, G.: "Emma Reyes". Periódico El Tiempo. Hechos Históricos: Bogotá. 9 de septiembre, (1996), p. 5. Caballero, L.: "El Mito de Emma Reyes". Emma Reyes y su Pintura. Excelsior Ediciones: Bogotá, (1996), p. 35. Calderón, C.: "Emma Reyes trajo su exposición de París". Revista Al día. s.f. pp. 50-51.

Cárdenas, O.L.: "Emma Reyes Pinceladas de Nostalgia". Revista Carrusel. p. 9.

Garzón, D.: “¿Qué pasó con Emma Reyes?”. Revista Soho. Edición 153, (2013), pp. 122-123. Herrera Gómez, F.: "Medio día en casa de Emma Reyes". Periódico El Mundo. Medellín. s.f. Janco, M.: "Emma Reyes": Hakidmah. Tel Aviv. (1993).

Catálogo del Museo de Arte Moderno La Tertulia. "La Pielroja Boyacense". Revista Semana. 5 de marzo. Makensie, E.: "Soy una Obrera del Arte". Periódico El Espectador. Bogotá. 22 de octubre. (1998).

Medina, A.: "Los cuarenta años de una línea." Revista Arte en Colombia. 31. Septiembre. Bogotá: Excelsior Ediciones. (1986), pp. 40-41.

Montaña, A.: "Emma Encuentra su Isla. Una Pintora Colombiana en Italia". Periódico El Tiempo. Bogotá, (1960), p. 5.

Montaña, A.: "La mano del oso y otros temas entorno a la pintura de Emma Reyes" en Emma Reyes y su Pintura.

Bogotá: Excelsior Ediciones. (1996), p. 64.

Penilla Céspedes, C.: "El Mito de Emma Reyes". Periódico El Tiempo. Lecturas Dominicales. Bogotá. 21 de abril. (1991), p. 13.

Pérez, A.: "Otra vez Emma Reyes". Periódico El Tiempo. Bogotá. Marzo. (1950), p. 11.

Porat, M.: "La Pintora Emma Reyes en Jerusalém”. Periódico Menorah, febrero de 1958. (1993)

Catálogo del Museo de La Tertulia. "Regreso a los Orígenes": Periódico El Tiempo. Bogotá. 17 de Octubre. (1952).

Reyes, E.: Carta manuscrita del 1de Julio escrita en París. (1983).

Reyes, E.: Carta manuscrita del 13 de Diciembre de escrita en Bordeaux. (1985).

Reyes, E.: "Mi primer Atelier en París". Revista El Aleph,. 112, enero-marzo, (2000) pp. 84-85.

Reyes, E.:"La primera y última exposición de Frida Khalo". Revista El Aleph, 113, abril-junio, .(2000), p. 10. Ríos, A./Vergel, M ${ }^{a}$ P.: Cajonesy Dechados: Memoria, vida y Obra de Emma Reyes. Libro en proceso de edición.

Cali: Editorial Pontificia Universidad Javeriana. (2014), p. 24.

Ruiz, C.E.: "Emma Reyes, una mujer que respeta sólo lo vivido". Revista El Aleph, 110, julio/sept. (1999), pp. 22, 24.

Traba, M.: 1961 Emma Reyes. Catálogo del Museo de Arte Moderno La Tertulia. (1993). Trujillo Valencia, O.P.: "Un Sueño de Alegría". Revista Cromos. (1988), p. 97.

Trijillo Valencia, O.P.: Entrevista el 31 de mayo. . (2014)

Valencia Diago, G.: "Emma Reyes, Una Anécdota Viviente". Emma Reyes y su Pintura. Bogotá: Excelsior Ediciones. (1996), p. 37.

Vergel, Ma P.: "Panorámica de una línea perpetua: Tres momentos en la obra de Emma Reyes" en Cajonesy Dechados: Memoria, vida y Obra de Emma Reyes. Libro en proceso de edición. Cali: Editorial Pontificia Universidad Javeriana. (2014), p. 26. 